\title{
Correlation Between Biomass Burning Tracers in Urban and Rural Particles in Silesia-Case Study
}

\author{
Katarzyna Janoszka ${ }^{\circledR} \cdot$ Marianna Czaplicka
}

Received: 7 September 2021 / Accepted: 26 January 2022 / Published online: 9 February 2022

(C) The Author(s) 2022

\begin{abstract}
The major biomass burning tracers are thermal degradation products from the biopolymer cellulose, namely the didehydromonosaccharide derivatives levoglucosan, galactosan, and mannosan and the resin acid derivative dehydroabietic acid, with a minor contribution from $\beta$-sitosterol. Levoglucosan, galactosan, and mannosan were measured at two sites in Silesia, a rural (Rokitno) and industry region (Zabrze), during the winter of 2017/2018. The results showed that mean concentrations of the total tracers determined were $737 \mathrm{ng} / \mathrm{m}^{3}$ for Zabrze and $465 \mathrm{ng} /$ $\mathrm{m}^{3}$ for Rokitno. Levoglucosan was the most abundant tracer; it was $83.2 \%$ of the determined tracers in Zabrze and $78.1 \%$ in Rokitno. The relative proportions of levoglucosan to mannosan have been used for source reconstruction of combustion-derived byproducts in atmospheric aerosols. The levoglucosan to mannosan ratio for Zabrze was 8.9 and for Rokitno 5.3; the levoglucosan to sum of mannosan and galactosan ratio was 6.2 and 3.8 for Zabrze and Rokitno, respectively. The correlation between tracers is high ( 0.73 to 0.97$)$ and shows linearity. In order to compare the fuel type (by the coefficient of divergence (CD)) between different sites, the results from a previous work in health resort Krynica were used. The CD
\end{abstract}

K. Janoszka $(\bowtie) \cdot$ M. Czaplicka

Institute of Environmental Engineering Polish Academy of Science, 34 M. Skłodowskiej-Curie Str, 41-819 Zabrze, Poland

e-mail: katarzyna.janoszka@ipispan.edu.pl between Krynica and Rokitno as well as Krynica and Zabrze was equal to 0.633 and 0.712 , respectively. The CD between Rokitno and Zabrze was equal to 0.175. Despite the biomass burning tracer measurements are mostly local, they have a huge impact on air pollution and climate changes.

Keywords Biomass burning $\cdot$ Tracers $\cdot$ Winter season $\cdot$ Coefficient of divergence
Abbreviations
LG Levoglucosan
MN Mannosan
GA Galactosan

\section{Introduction}

During the burning of biomass, which consist mainly of cellulose, at a temperature above $300{ }^{\circ} \mathrm{C}$, levoglucosan (LG, 1,6-anhydro- $\beta$-glucopyranose) is created, as well as the levoglucosan isomers mannosan (MN) and galactosan (GA) which are products of hemicellulose burning. It is well known that levoglucosan, mannosan, and galactosan are biomass burning tracers. Those tracers are believed to be stable in the environment and resistant to photochemical oxidation (Jordan et al., 2006; Piot et al., 2012; Schkolnik \& Rudich, 2006). However, it is shown that tracers are not inert and their lifetime depends on the $\mathrm{OH}$ radical concentration. At chamber experiments simulating 
typical summertime $\mathrm{OH}$ concentration $\left(4.9 \times 10^{10}\right.$ molecules $\left.\mathrm{cm}^{-3} \mathrm{~s}\right)$, the levoglucosan was stable for 0.7 to 2.2 days (Hennigan et al., 2010, 2011). Because our study took place during the winter and the local biomass burning is a source of levoglucosan, it is assumed that LG is sufficiently stable to be used as a tracer. Sugar anhydrides are in the particular phase in the atmosphere because of their low vapor pressure and they can, for example, affect the earth radiation budget and act as cloud condensation nuclei (Janoszka \& Czaplicka, 2019; Poor, 2002; Schkolnik \& Rudich, 2006; Simoneit et al., 1999). Biomass burning emission can interfere with carbon bio- and geochemical cycling, the chemistry of the tropospheric, and furthermore, when deposited on glacier and ice sheets, reduce snow albedo and accelerate melting (Bhattarai et al., 2019; Xu \& You, 2021; Galindo et al., 2021). Puxbaum et al. (2007) indicate that in the winter, the contribution of biomass combustion is higher than in the summer, because of lower temperatures which cause slower air mass exchange in the atmosphere and higher smoke emission. The biomass burning tracers may be used for determination of the products burned, for example, in domestic furnaces. Because the biomass smoke may have different sources, like wild fires, agricultural burns, and domestic heating as well as long-range transport, the concentrations of levoglucosan observed are characterized by high variability. For example, the average LG concentration in the Po Valley (Northern Italy) was $176 \mathrm{ng} / \mathrm{m}^{3}$ and 19.3 and $12.8 \mathrm{ng} / \mathrm{m}^{3}$ in $\mathrm{MN}$ and GA, respectively (Saarikoski et al., 2012). Mkoma et al. (2013) reported the values of 209 and $308 \mathrm{ng} / \mathrm{m}^{3}$ for levoglucosan in the wet and dry season, respectively and $20 \mathrm{ng} / \mathrm{m}^{3}$ for mannosan in the wet and $30 \mathrm{ng} / \mathrm{m}^{3}$ in the dry season.

The ratios of levoglucosan to mannosan and levoglucosan to the sum of mannosan and galactosan may be used to distinguish between different types of fuel burned when analyzing atmospheric aerosols. However, caution must be taken in the interpretation of environmental samples because of smoke mixing and high values of $\mathrm{LG} / \mathrm{MN}$ ratios for grasses and different hardwood (Fabbri et al., 2009; Schmidl et al., 2008). For example, the LG/MN ratio in the case of combustion of American beech was 17 and for White spruce 4 (Piot et al., 2012).

The authors indicate a correlation between air pollutants and the type of emission source. One of these dependences is the coefficient of divergence (CD), a self-normalizing parameter for comparison of chosen species concentration. Tan et al. (2014) used the $\mathrm{CO}, \mathrm{NO}_{\mathrm{x}}$, and $\mathrm{SO}_{\mathrm{x}}$ concentration to compare sampling sites in term of pollutants. Jiang et al. (2018) and Kong et al. (2011) used $\mathrm{PM}_{2.5}$ and $\mathrm{PM}_{10}$ concentration.

Considering the need to monitor air quality for the presence of pollutants and their impact on climate change, it is important to have knowledge of the biomass burning tracer concentrations in the air. It is known that due to their physicochemical properties, they affect aerosol grain sizes and cloud formation processes (Dixon \& Baltzell, 2006; Gao et al., 2003; Graham et al., 2002; Oros \& Simoneit, 2001; Schkolnik \& Rudich, 2006). In Poland, there is a lack of research on biomass burning tracer concentrations in atmospheric aerosols. The knowledge about the local biomass burning, like in densely populated area of Upper Silesia Agglomeration, may have an impact on the larger area of the country. Moreover, there are more and more regulations in Poland enforcing higher requirements for heat sources. The Upper Silesian Agglomeration and the whole Silesian Voivodeship are regulated by an anti-smog law. It obligates the inhabitants to replace the heat sources with ecological ones. The schedule assumes replacement of all out-of-class boilers or those older than 10 years by the end of 2021 . The modern boilers with feeders (eco-pea hard coal, pellet) at least fifth eco-design class, gas boilers, heat pumps, or electric boilers are allowed (Resolution of the Sejmik no. V/36/1/2017). The most promoted solutions are heat pumps and pellet boilers. Similar resolutions are in force in most of the country. Further monitoring will assess the impact of the ordinances on atmospheric pollution.

Therefore, within the framework of this article, the objectives were to (i) determine the level of biomass burning tracer concentrations in air samples for two sites, industry region and rural area, during the winter season 2017/2018, (ii) investigate the relationship between biomass burning tracers, and (iii) estimate the coefficient of divergence.

\section{Experimental and Methodology}

Atmospheric aerosol samples were collected on quartz filters at measurement stations situated in 
southern Poland, in Zabrze (industry region, urban background, located in the center of Upper Silesia Agglomeration, $\varphi=50^{\circ} 18^{\prime} 53^{\prime \prime} \mathrm{N}, \quad \lambda=18^{\circ} 46^{\prime} 17^{\prime \prime} \mathrm{E}$, $h=254 \mathrm{~m}$ above sea level, a.s.l.,) and Rokitno (rural area, rural background, open area near small village situated close to the zinc and lead ores, $\varphi=50^{\circ} 26^{\prime} 09^{\prime \prime} \mathrm{N}, \lambda=19^{\circ} 25^{\prime} 29^{\prime \prime} \mathrm{E}, h=344 \mathrm{~m}$ a.s.l.) from December 2017 to March 2018 (Fig. 1). In order to compare the results between different sites, the measurements from a previous work in health resort Krynica (rural background, slope of the mountain valley, $\varphi=49^{\circ} 24^{\prime} 28^{\prime \prime} \mathrm{N}, \lambda=20^{\circ} 57^{\prime} 39^{\prime \prime} \mathrm{E}, h=582 \mathrm{~m}$ a.s.l.) were used. Samples were collected in accordance with the methodology previously described (Janoszka et al., 2020; Klejnowski et al., 2017) with the use of a low flow sampler with a $\mathrm{PM}_{10}$ separating head (Atmoservice PNS3D15/LVS3d) and a stabilized flow of $2.3 \mathrm{~m}^{3} / \mathrm{h}$ at a $24-\mathrm{h}$ cycle on $47-\mathrm{mm}$ Whatman QMA quartz filters.

PN-EN 12,341:2014 (ambient air) was used for sample collection and gravimetric. A standard gravimetric measurement method for the determination of the $\mathrm{PM}_{10}$ mass concentration of suspended particulate matter of every sample filter was used. Conditioning, weighing (Mettler Toledo microbalance with resolution $2 \mu \mathrm{g}$ ), and storage of exposed and non-exposed filters were done at a weighing room with control conditions (dryer and humidifier) with temperature $20 \pm 1{ }^{\circ} \mathrm{C}$ and humidity $45 \pm 5 \% \mathrm{RH}$.

In order to determine the concentration of biomass burning tracers (levoglucosan, mannosan, and galactosan), a sample of atmospheric aerosol collected on a quartz filter was extracted and derivatized at the same time according to the methodology previously

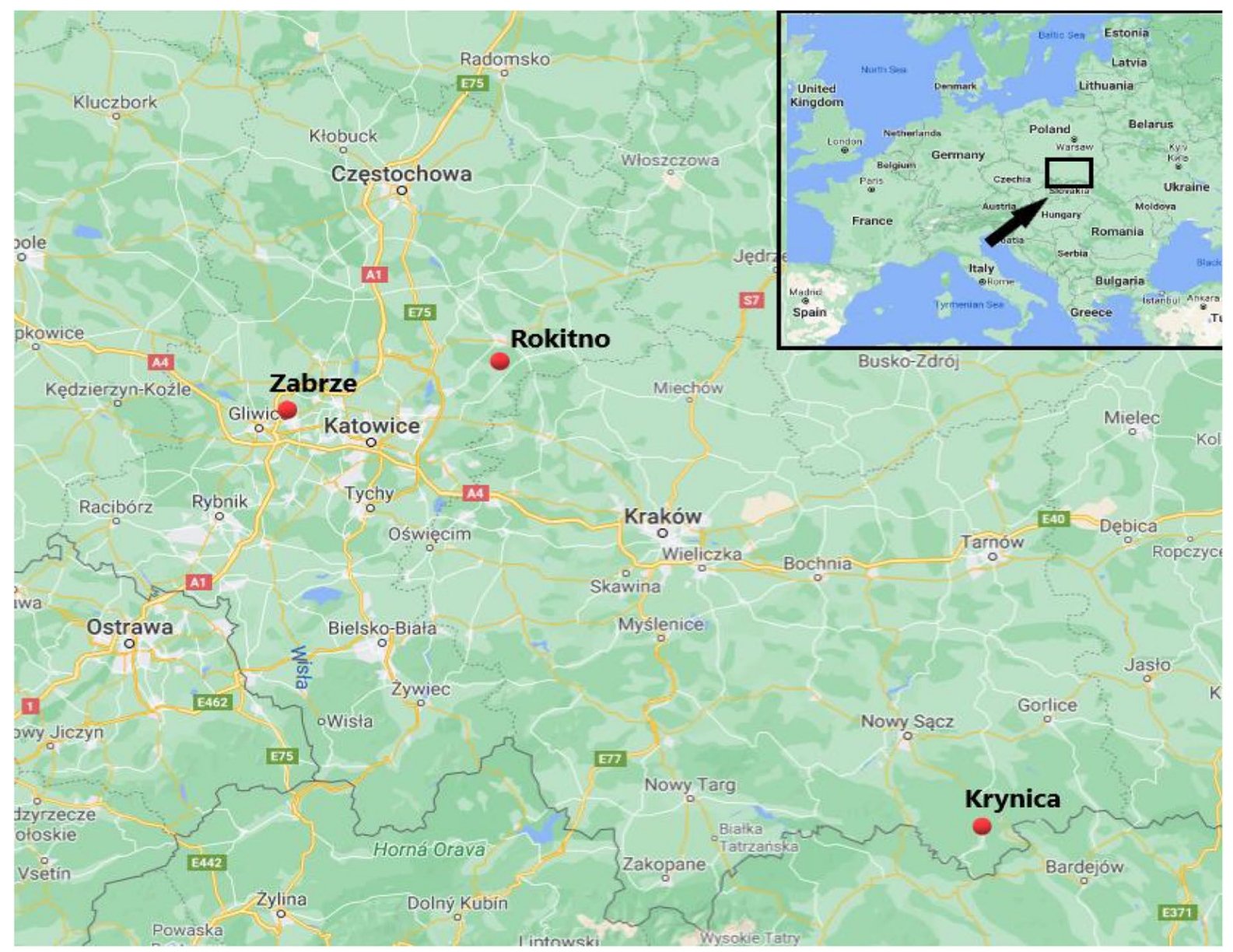

Fig. 1 Sampling site position 
described (Janoszka et al., 2020). Briefly, the sample was placed in a 4-ml dark glass vial; $2 \mathrm{ml}$ of pyridine $(\mathrm{POCH})$ and $50 \mu \mathrm{l}$ of a derivatizing agent and a mixture of N,O-bis(trimethylsilyl)trifluoroacetamide and trimethylchlorosilane (BSTFA:TMCS, 99:1, Supelco) were added. The vial was closed, shaken for $1 \mathrm{~min}$, and placed in an oven at $40{ }^{\circ} \mathrm{C}$ for $30 \mathrm{~min}$. After reaction, $1 \mathrm{ml}$ of the extract was filtered through a syringe filter $(0.22 \mu \mathrm{m})$ and analyzed using a Shimadzu GC-2010 gas chromatograph coupled with a mass spectrometry detector equipped with an HP-5MS column $(30 \mathrm{~m}, 0.25 \mathrm{~mm}, 0.25 \mu \mathrm{m})$. The limit of detection (LOD) was equal to $3.33 \mathrm{ng} / \mathrm{ml}$ for $\mathrm{LG}, 1.50 \mathrm{ng} /$ $\mathrm{ml}$ for $\mathrm{MN}$, and $1.53 \mathrm{ng} / \mathrm{ml}$ for GA. The limit of quantification (LOQ) was equal to $9.99,4.51$, and $4.58 \mathrm{ng} /$ $\mathrm{ml}$ for $\mathrm{LG}, \mathrm{MN}$, and GA, respectively. The precision expressed as a relative standard deviation was equal to $19 \%$.

\section{Result and Discussion}

The mass concentration of $\mathrm{PM}_{10}$ and biomass burning tracer concentrations (levoglucosan, mannosan, and galactosan) are statistically summarized in Tables 1 and 2 and Figs. 2 and 3.

Table 1 Concentration of $\mathrm{PM}_{10}$ by months and for the entire sampling period at both sites

\begin{tabular}{lll}
\hline Month & Rokitno, $\mu \mathrm{g} / \mathrm{m}^{3}$ & Zabrze, $\mu \mathrm{g} / \mathrm{m}^{3}$ \\
\hline December & 20.4 & 58.8 \\
January & 23.2 & 55.1 \\
February & 30.5 & 69.9 \\
March & 25.2 & 75.3 \\
Average & 24.8 & 64.8 \\
\hline
\end{tabular}

The average mass concentration of $\mathrm{PM}_{10}$ (Table 1) was $24.83 \mu \mathrm{g} / \mathrm{m}^{3}$ at the rural area Rokitno which is higher than at a rural background site in Vindeln, Sweden with about $5 \mu \mathrm{g} / \mathrm{m}^{3}$ of $\mathrm{PM}_{10}$ (Hedberg et al., 2006). The average $\mathrm{PM}_{10}$ concentration value at the industrial area Zabrze was $64.78 \mu \mathrm{g} / \mathrm{m}^{3}$. This is higher than the winter average $\mathrm{PM}_{10}$ concentration value of $43 \mu \mathrm{g} / \mathrm{m}^{3}$ for Launceston, Australia (Jordan et al., 2006), and $56.83 \mu \mathrm{g} / \mathrm{m}^{3}$ for Lhasa, Tibet (Yin et al., 2019), but more than 2 times lower than in urban Beijing with a mean $\mathrm{PM}_{10}$ concentration of $169 \mu \mathrm{g} / \mathrm{m}^{3}$ (Zhang et al., 2008).

The level of average $\mathrm{PM}_{10}$ concentration in most months in Rokitno was from 20.41 to $30.53 \mu \mathrm{g} / \mathrm{m}^{3}$. In Zabrze, the mean concentration for each month is higher, from 55.13 to $75.29 \mu \mathrm{g} / \mathrm{m}^{3}$.

Biomass burning tracers are frequently detected in terms of atmospheric pollution. For example, the average concentration of the tracers at an urban background site in Helsinki during winter 2008-2009 was $90 \mathrm{ng} / \mathrm{m}^{3}$ (Saarnio et al., 2010) and $630 \mathrm{ng} / \mathrm{m}^{3}$ for Beijing and Shijiazhuang, China, from 1 to 12 November 2014 (Zhang et al., 2017).

The average tracer concentrations during the measurement campaign were $465 \mathrm{ng} / \mathrm{m}^{3}$ for Rokitno and $736 \mathrm{ng} / \mathrm{m}^{3}$ for Zabrze. In the case of levoglucosan, the average campaign concentration was 366 and $606 \mathrm{ng} / \mathrm{m}^{3}$ for Rokitno and Zabrze, respectively. The mannosan average campaign concentration was $66.6 \mathrm{ng} / \mathrm{m}^{3}$ for Rokitno and $96.9 \mathrm{ng} / \mathrm{m}^{3}$ for Zabrze. For galactosan, the average concentration was 33.0 and $33.5 \mathrm{ng} / \mathrm{m}^{3}$ for Rokitno and Zabrze, respectively (Fig. 4).

In December 2017 and January and March 2018, the average concentration of biomass burning tracers in atmospheric aerosol was higher at the sampling point in Zabrze being 902, 646, and $449 \mathrm{ng} /$
Table 2 Average concentration of biomass burning tracers at each site by month

\begin{tabular}{lllllc}
\hline Site & Month & Sum, ng/m & LG, $\mathrm{ng} / \mathrm{m}^{3}$ & $\mathrm{MN}, \mathrm{ng} / \mathrm{m}^{3}$ & $\mathrm{GA}, \mathrm{ng} / \mathrm{m}^{3}$ \\
\hline Rokitno & December & 440 & 327 & 83.2 & 30.1 \\
& January & 224 & 188 & 27.9 & 7.5 \\
& February & 1005 & 806 & 119 & 80.0 \\
\multirow{4}{*}{ Zabrze } & March & 192 & 142 & 36.2 & 14.2 \\
& December & 902 & 674 & 177 & 55.2 \\
& January & 646 & 502 & 111 & 32.9 \\
& February & 946 & 846 & 67.9 & 32.4 \\
& March & 449 & 403 & 31.8 & 13.6 \\
\hline
\end{tabular}




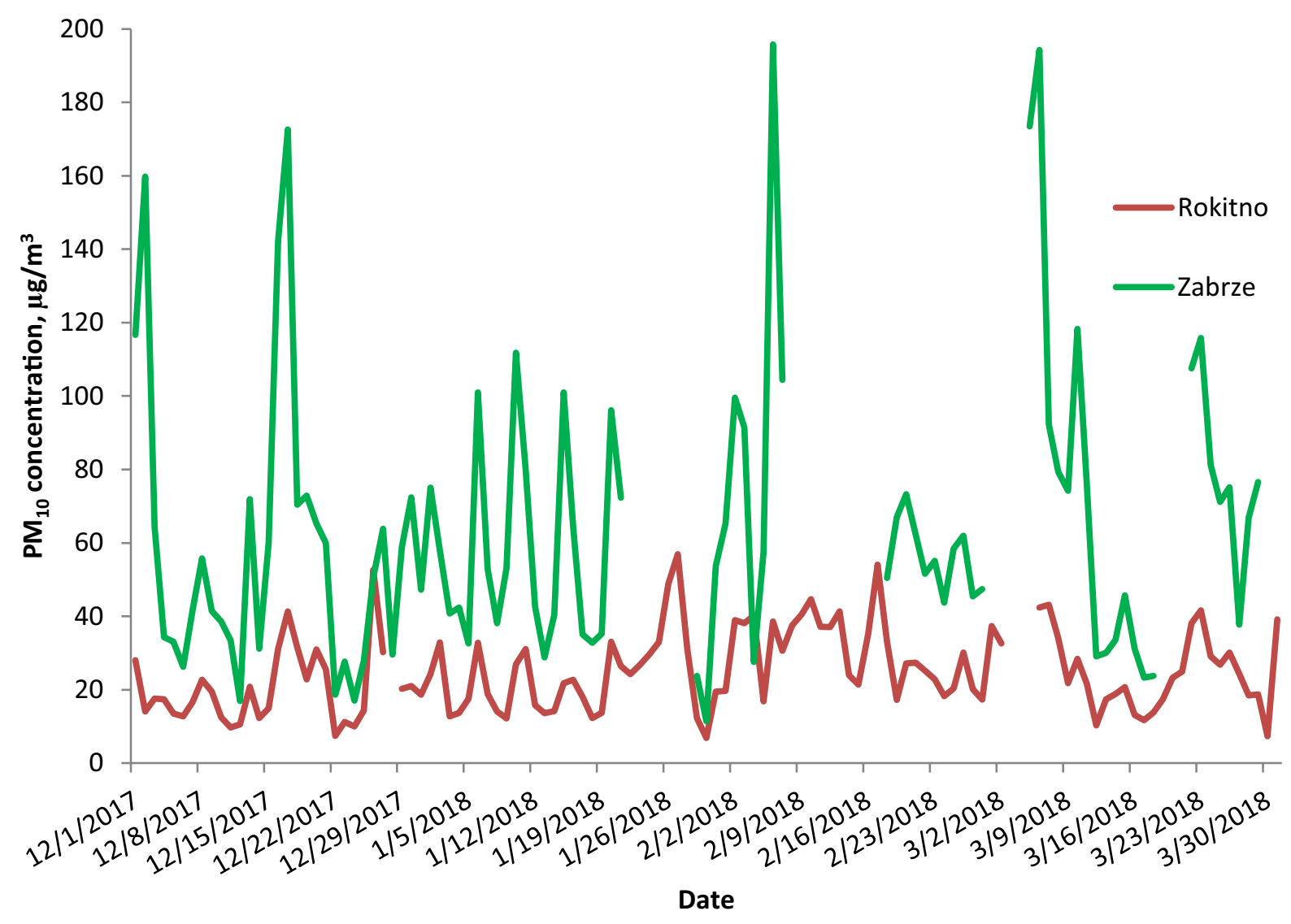

Fig. 2 Variations of $\mathrm{PM}_{10}$ concentrations at the sampling sites

$\mathrm{m}^{3}$, respectively. In February, the higher total tracer concentration in Rokitno was equal to $1005 \mathrm{ng} / \mathrm{m}^{3}$ (Table 2).

Zabrze is an industrial city with 170,000 inhabitants surrounded by single-family houses with individual furnaces. Therefore, the higher biomass burning tracer concentrations are caused by higher emissions from biomass combustion and domestic heating. Rokitno is a village in a rural area with about 900 inhabitants and characterized with lower tracer concentration.

The results for single tracers can be very diverse. For example, in Malaysia the concentration of levoglucosan varies from $10 \mathrm{ng} / \mathrm{m}^{3}$ at Taman Negra up to $34,000 \mathrm{ng} / \mathrm{m}^{3}$ at the University of Malaya (Petaling Jaya) at night (Abas et al., 2004).

In the case of the rural area Rokitno, the mean concentration varies from $192 \mathrm{ng} / \mathrm{m}^{3}$ in March to $1005 \mathrm{ng} / \mathrm{m}^{3}$ in February (Fig. 5). The highest average concentration of biomass burning tracers for the industry region in Zabrze was measured in February and was equal to $946 \mathrm{ng} / \mathrm{m}^{3}$, while the lowest concentration of $449 \mathrm{ng} / \mathrm{m}^{3}$ was determined in March (Fig. 6).

Of the determined biomass burning tracers, the dominant compound was levoglucosan. The mean LG concentration determined during the measurement campaign varies from 142 to $806 \mathrm{ng} / \mathrm{m}^{3}$ for Rokitno and from 403 to $846 \mathrm{ng} / \mathrm{m}^{3}$ for Zabrze. In the case of mannosan, the mean values for Rokitno vary from 27.9 to $119 \mathrm{ng} / \mathrm{m}^{3}$ and for Zabrze vary from 31.8 to $177 \mathrm{ng} / \mathrm{m}^{3}$. The galactosan is the least abundant of the determined tracers and it varies from 7.5 to $80.0 \mathrm{ng} / \mathrm{m}^{3}$ and from 13.6 to $55.2 \mathrm{ng} /$ $\mathrm{m}^{3}$ for Rokitno and Zabrze, respectively. These results correspond to the previous work by Hedberg et al. (2006) where the mean LG concentration at urban Lycksele, Sweden, equaled to $896.6 \mathrm{ng} / \mathrm{m}^{3}$, 


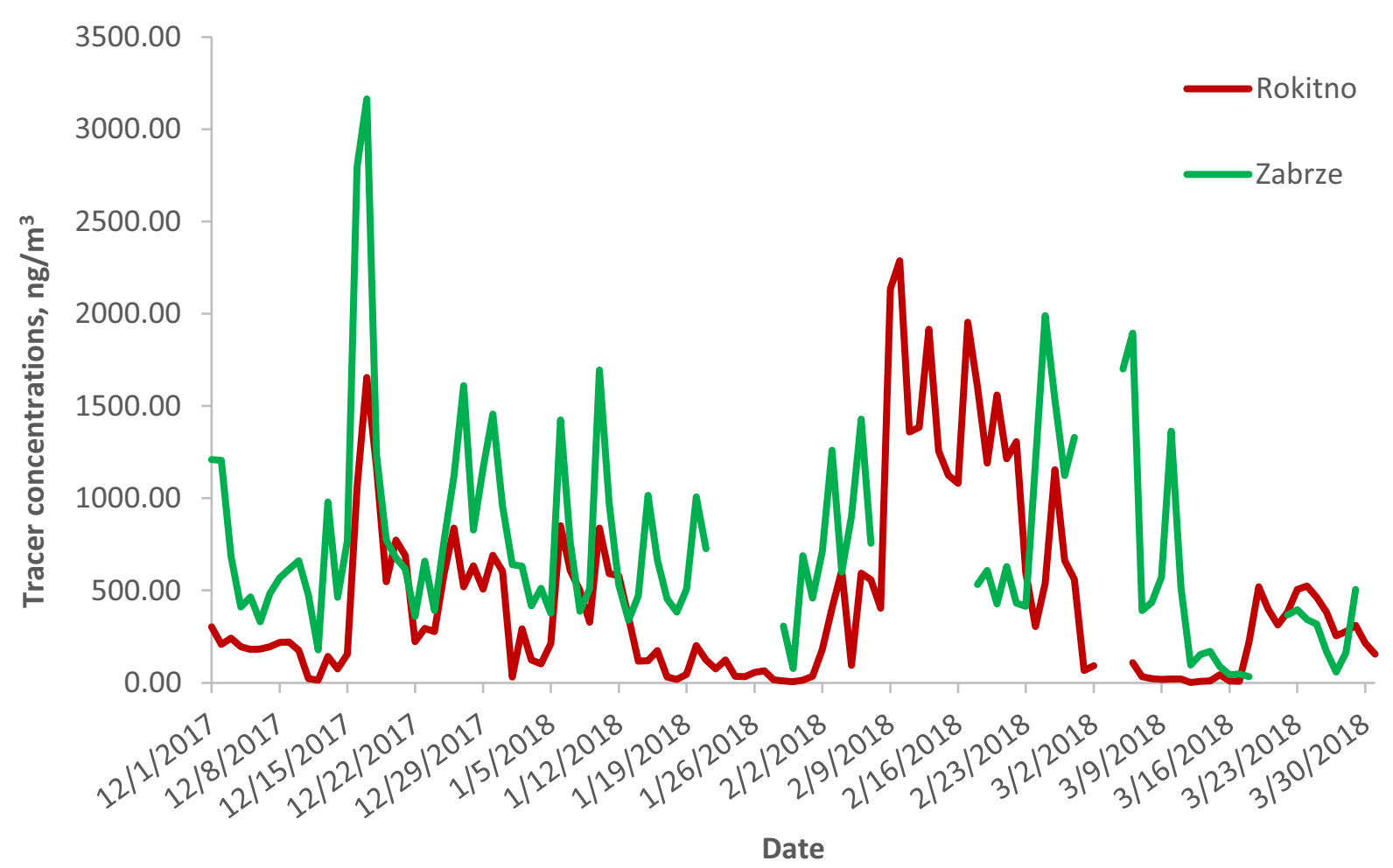

Fig. 3 Variations of the sum of the biomass burning tracer concentrations at the two sampling sites

Fig. 4 The average concentration for the sum of the biomass burning tracers at each site by month

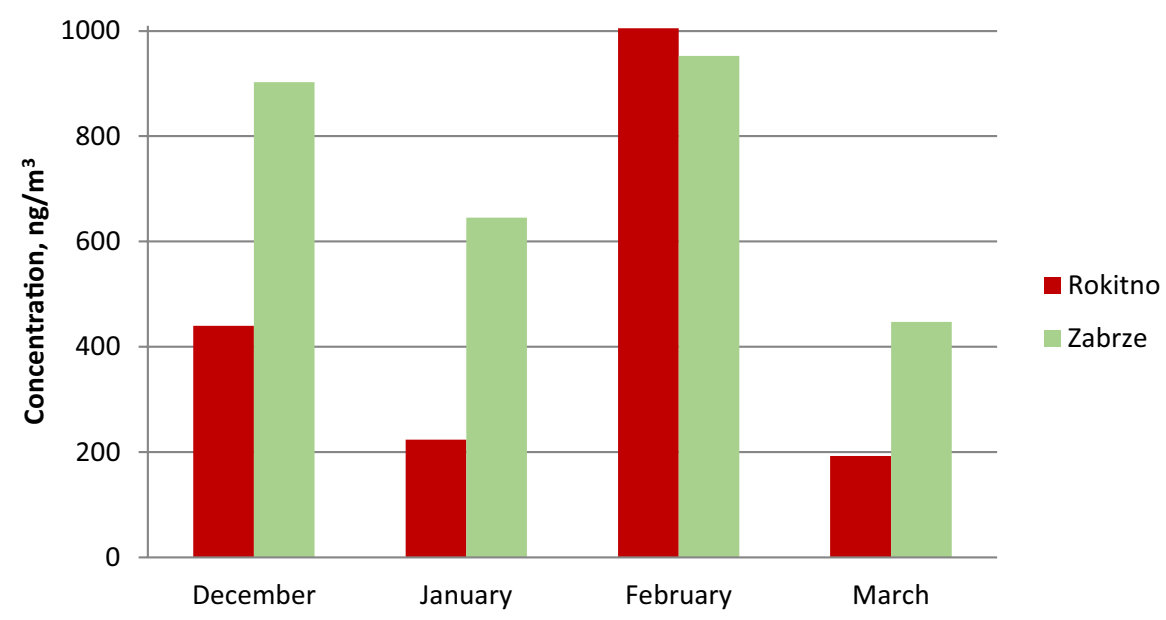

with the minimum and maximum value of 16.5 and $2335.4 \mathrm{ng} / \mathrm{m}^{3}$, respectively. The result in the Po Valley, Italy, for LG was $176 \mathrm{ng} / \mathrm{m}^{3}$, for MN $19.3 \mathrm{ng} /$ $\mathrm{m}^{3}$, and for GA $12.8 \mathrm{ng} / \mathrm{m}^{3}$ (Saarikoski et al., 2012). In the case of Morogoro, Tanzania, East Africa LG and $\mathrm{MN}$ mean concentrations in the wet season were equal to 209 and $20 \mathrm{ng} / \mathrm{m}^{3}$, respectively, and in the dry season were 308 and $30 \mathrm{ng} / \mathrm{m}^{3}$, respectively (Mkoma et al., 2013).

In the case of Rokitno, the total determined tracer concentrations vary from $1.2 \mathrm{ng} / \mathrm{m}^{3}$ determined on 12.03.2018 to $1710 \mathrm{ng} / \mathrm{m}^{3}$ on 10.02 .2018 . For Zabrze, the lowest total biomass burning tracer concentration was $33.7 \mathrm{ng} / \mathrm{m}^{3}$ determined on 18.03 .2018 , and the 
Fig. 5 Average monthly concentration of biomass burning tracers in atmospheric aerosol in Rokitno
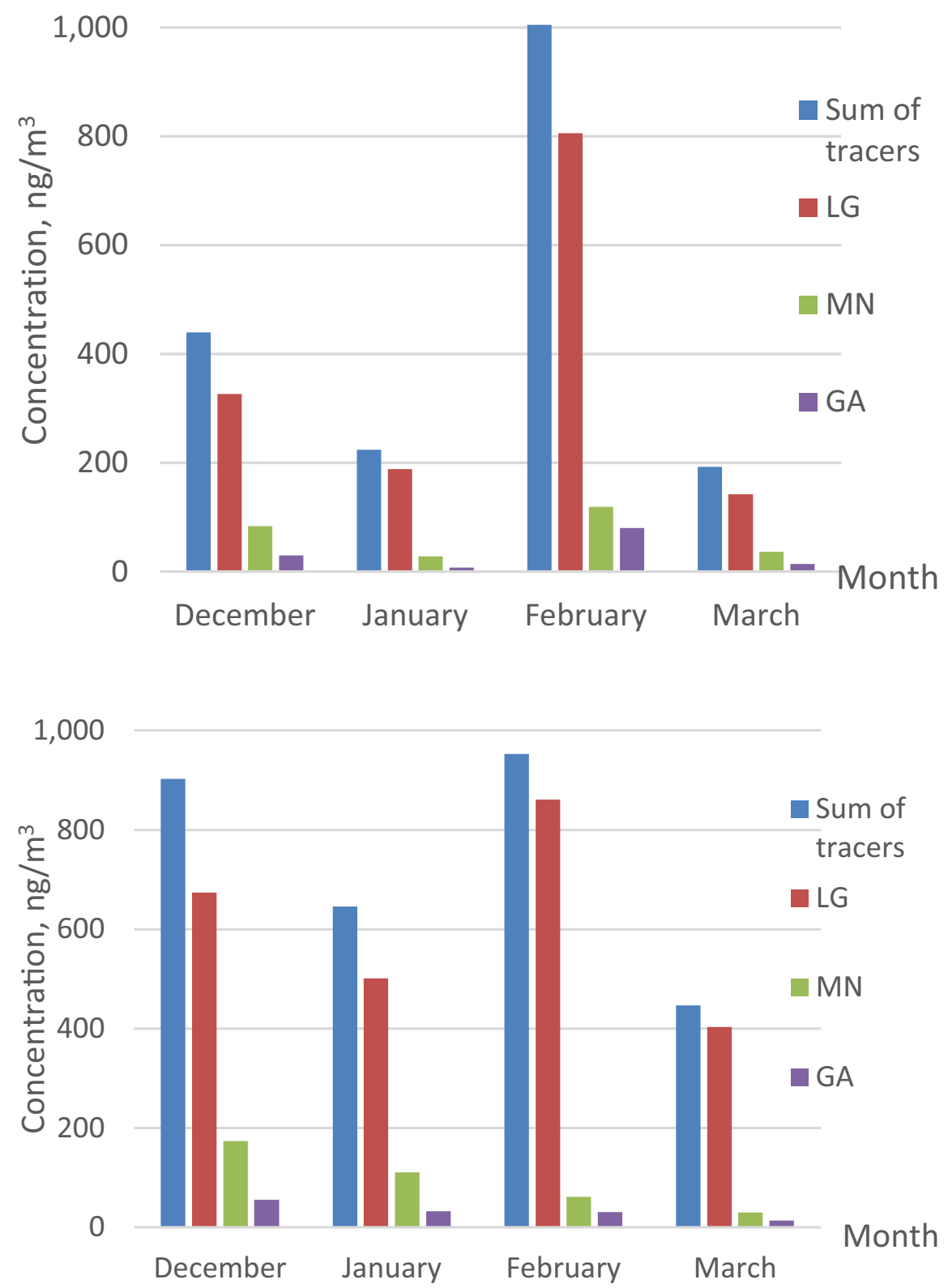

December January February March
Fig. 6 Average monthly concentration of biomass burning tracers in atmospheric aerosol in Zabrze highest value of total concentration was $3165 \mathrm{ng} / \mathrm{m}^{3}$ on 17.12.2017.

In the case of the rural area Rokitno, the mean percentage of individual tracers in the total sum was $78.1 \%, 15.5 \%$, and $6.4 \%$ for $\mathrm{LG}, \mathrm{MN}$, and $\mathrm{GA}$, respectively. In the industry region (Zabrze), the LG was on average $82.8 \%$, MN was $12.7 \%$, and GA was $4.4 \%$ (Table 3).

Galactosan is the least occurring tracer and levoglucosan is the dominant biomass burning tracer in each measurement point. In the case of Zabrze, the
LG percentage is above $80 \%$. The galactosan percentage is less than $10 \%$. The mannosan percentage of the sum varies from 12.7 to $15.5 \%$. A similar relationship was observed by Saarikoski et al. (2012) in the Po Valley, Italy, with LG percentage of $84.4 \%$, MN of $9.56 \%$, and GA of $6.0 \%$.

The relative proportion of levoglucosan to mannosan (LG/MN) and levoglucosan to the sum of mannosan and galactosan ( $\mathrm{LG} /(\mathrm{MN}+\mathrm{GA}))$ may be utilized to distinguish the smoke emission for different fuel types. The results obtained by Rodrigues et al. 
Table 3 Percentages of biomass burning tracers in the total sum of compounds by month at each site

\begin{tabular}{lllll}
\hline & Month & LG \% & MN \% & GA \% \\
\hline Rokitno & December & 74.2 & 18.9 & 6.8 \\
& January & 84.2 & 12.5 & 3.3 \\
& February & 80.2 & 11.9 & 8.0 \\
\multirow{7}{*}{ Zabrze } & March & 73.8 & 18.8 & 7.4 \\
& December & 74.4 & 19.5 & 6.1 \\
& January & 77.7 & 17.2 & 5.1 \\
& February & 89.4 & 7.2 & 3.4 \\
& March & 89.9 & 7.1 & 3.0 \\
\hline
\end{tabular}

Table 4 The LG/MN and LG/(MN + GA) ratios as well as the average temperature by month for each site

\begin{tabular}{|c|c|c|c|c|}
\hline & Month & LG/MN & $\begin{array}{l}\text { LG/ } \\
(\mathbf{M N}+\mathbf{G A})\end{array}$ & $\begin{array}{l}\text { Tem- } \\
\text { perature, } \\
{ }^{\circ} \mathrm{C}\end{array}$ \\
\hline \multirow[t]{4}{*}{ Rokitno } & December & 3.9 & 2.9 & 0.8 \\
\hline & January & 6.7 & 5.3 & 0.2 \\
\hline & February & 6.8 & 4.0 & -4.4 \\
\hline & March & 3.9 & 2.8 & -0.4 \\
\hline \multirow[t]{4}{*}{ Zabrze } & December & 3.9 & 2.9 & 2.5 \\
\hline & January & 4.5 & 3.5 & 3.0 \\
\hline & February & 12.5 & 8.4 & -2.9 \\
\hline & March & 12.7 & 8.9 & 2.1 \\
\hline
\end{tabular}

Fig. 7 The levoglucosan concentration plotted against the mannosan concentration at Rokitno
(2020) with a LG/MN ratio equal to 5.68 and a LG/ $(\mathrm{MN}+\mathrm{GA})$ ratio of 2.85 indicated softwood burning in Mt. Wellington, (Hobart, Tasmania, Australia); the results of 10.19 and 4.25 for LG/MN and LG/ $(\mathrm{MN}+\mathrm{GA})$, respectively, indicate higher hardwood contribution in Gingin (Western Australia). Mkoma et al. (2013) reported LG/MN ratio values equal to about 10 to 13 which suggested hardwood and crop residue burning.

The mean value of the LG/MN ratio for the rural area Rokitno was 5.3 and for the industry region Zabrze was equal to 8.4. The mean value of the LG/ $(\mathrm{MN}+\mathrm{GA})$ ratio was equal to 3.8 and 5.9 for Rokitno and Zabrze, respectively (Table 4). The results indicate that in Rokitno softwood burning was dominant and in Zabrze the co-combustion of softwood with hardwood.

The correlation coefficient of the mannosan and levoglucosan ratio was 0.79 for Rokitno and 0.60 for Zabrze. The correlation coefficient of the GA and LG ratio was 0.81 for Rokitno and 0.60 for Zabrze. In the case of the galactosan and mannosan ratio, the result was 0.78 and 0.96 for Rokitno and Zabrze, respectively. The correlation coefficient for the tracer ratios shows high correlation with linear regression (Figs. 7, $8,9,10,11$, and 12).

These results correspond to that obtained by Sullivan et al. (2014) who observed GA/LG correlation coefficient from 0.80 to 0.88 and MN/LG from 0.97 to 0.99 . Levoglucosan and mannosan strongly correlated in measurements from Tanzania and the Po

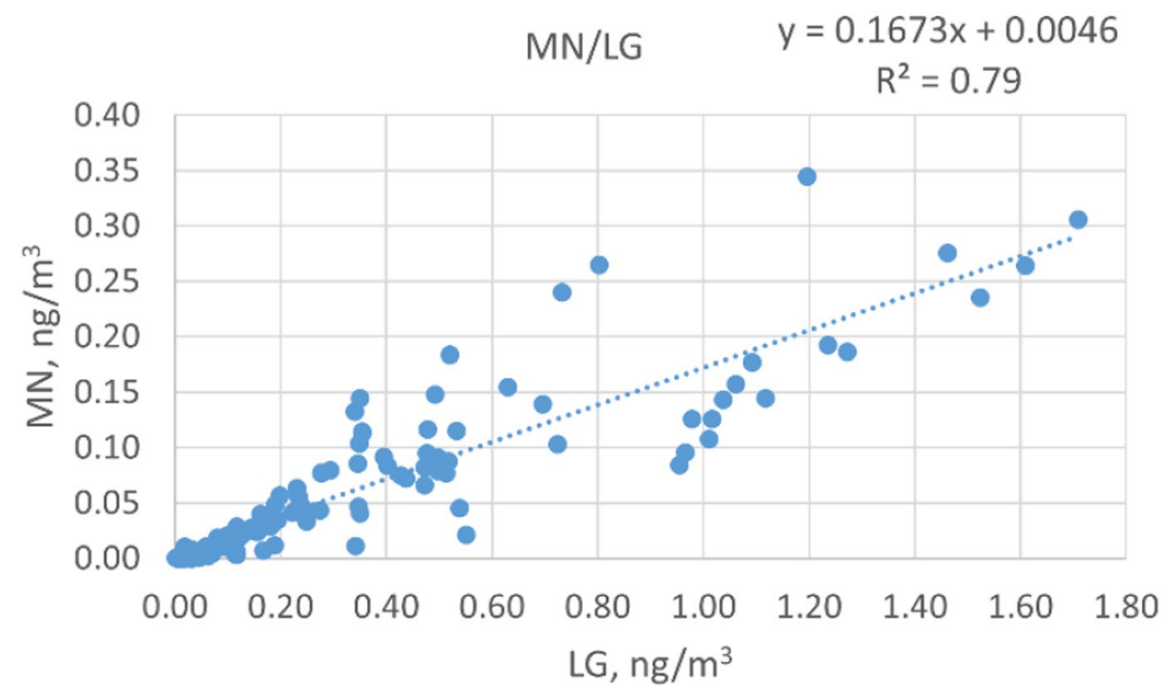


Fig. 8 The levoglucosan concentration plotted against the galactosan concentration at Rokitno
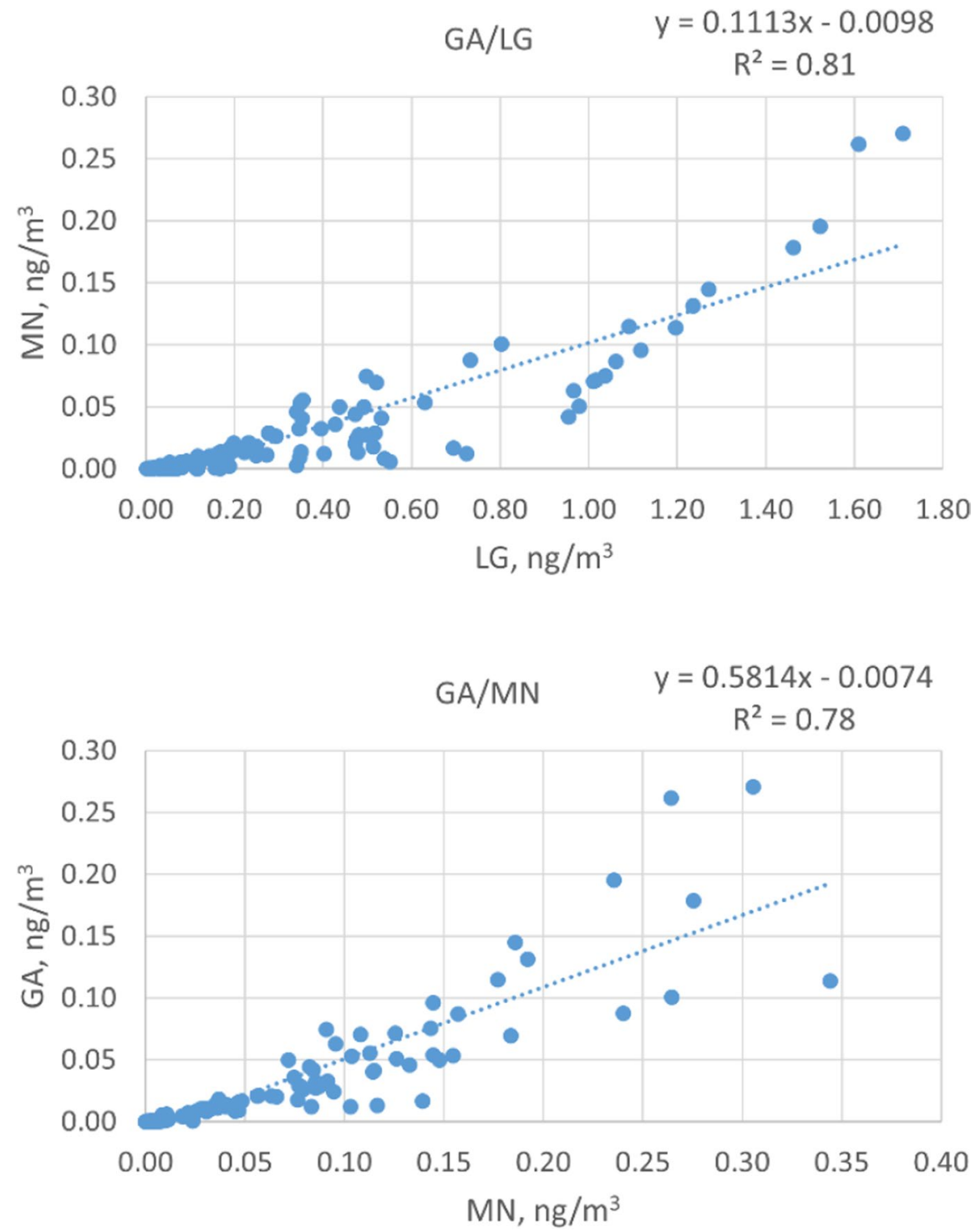

Fig. 9 The mannosan concentration plotted against the galactosan concentration at Rokitno
The PM from wood burning mean estimated concentration can be calculated according to Puxbaum et al. (2007) and Fuller et al. (2014). A factor of 7.35 is suggested to convert mean LG concentration to organic carbon and additional factor of 1.4 for biomass organic matter. Caseiro and Oliveira (2012) show the similar relationship with biomass smoke PM was equal to mean LG concentration multiplied by the factor of 10.7. The PM estimated concentration from wood burning for Rokitno was $3.76 \mu \mathrm{g} / \mathrm{m}^{3}$ and for Zabrze was $6.24 \mu \mathrm{g} / \mathrm{m}^{3}$. Those results are higher than for Kensington, England, which was $1.8 \mu \mathrm{g} / \mathrm{m}^{3}$ (Fullet et al., 2014) as well as for roadside sampling $\mathrm{PM}$ ratio (\%) ranging from 0.20 to 0.78 . 
Fig. 10 The levoglucosan concentration plotted against the mannosan concentration at Zabrze
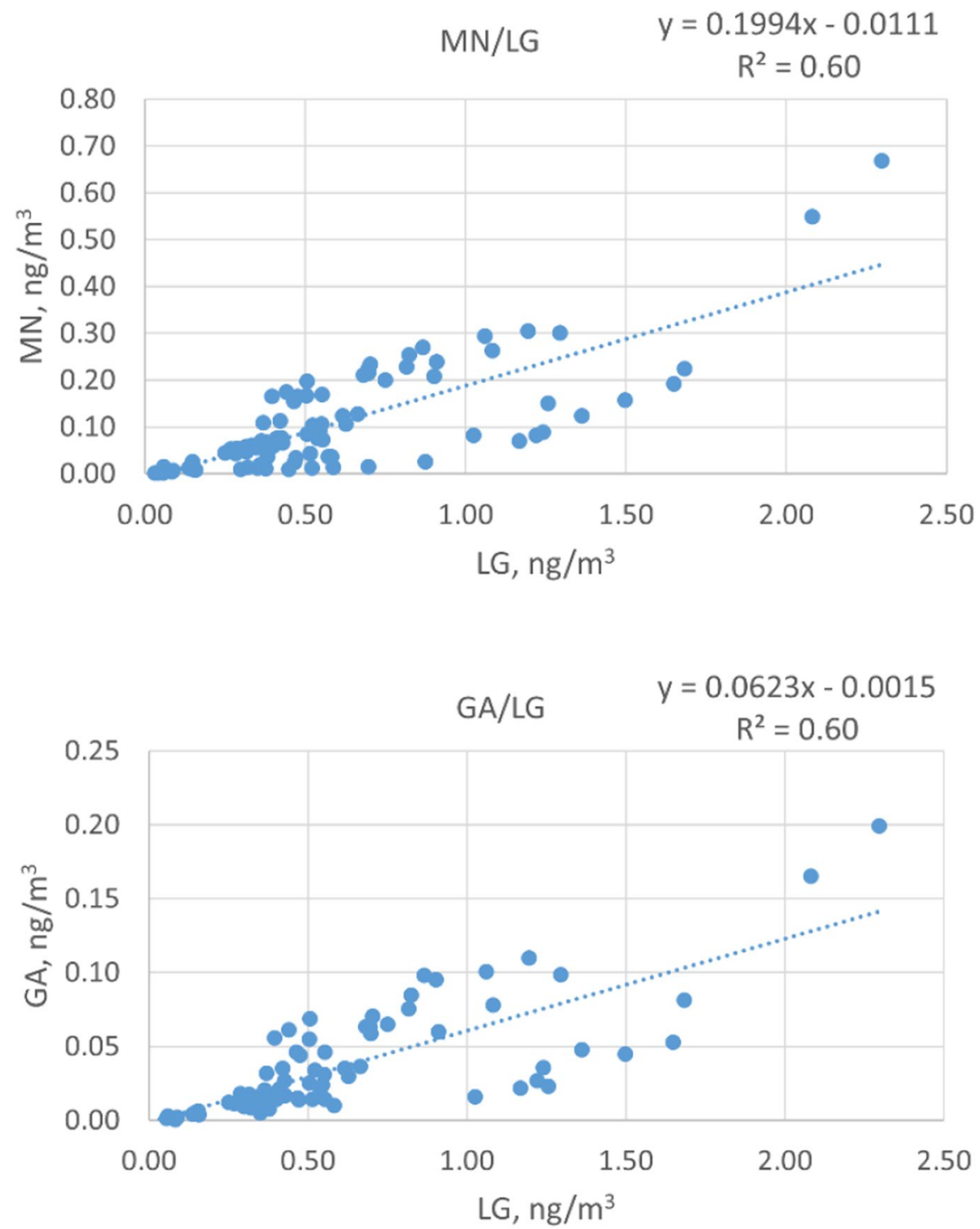

Fig. 11 The levoglucosan concentration plotted against the galactosan concentration at Zabrze point in Copenhagen and Oporto of 1.12 and $1.8 \mu \mathrm{g} /$ $\mathrm{m}^{3}$, respectively (Caseiro and Oliveira, 2012).

The coefficient of divergence (CD) allows for quantifying the similarities between two sampling points (emission sources) (Jiang et al., 2018; Kong et al., 2011; Li et al., 2020; Tan et al., 2014).

$C D_{j k}=\sqrt{\frac{1}{\rho} \sum_{i=1}^{\rho}\left(\frac{X_{i j}-X_{i k}}{X_{i j}+X_{i k}}\right)^{2}}$

where $j$ and $k$ are sampling points, $X_{i j}$ and $X_{i k}$ are average concentration of biomass burning tracer for a given sampling site, and $\rho$ is three because there are 3 biomass burning tracers: levoglucosan, mannosan, and galactosan. If the coefficient of divergence approaches zero, the sources of emission are similar and if the $\mathrm{CD}$ goes to one, the sources at the sampling sites are relevantly different. It is assumed that when the $\mathrm{CD}$ is higher than 0.31 , there is a considerable difference between the profiles at the two sampling sites. Li et al. (2020) used the phthalate concentration to determine the CD parameter and Tan et al. (2014) used $\mathrm{CO}, \mathrm{NO}_{\mathrm{x}}$, and $\mathrm{SO}_{2}$ concentrations. 
Fig. 12 The mannosan concentration plotted against the galactosan concentration at Zabrze

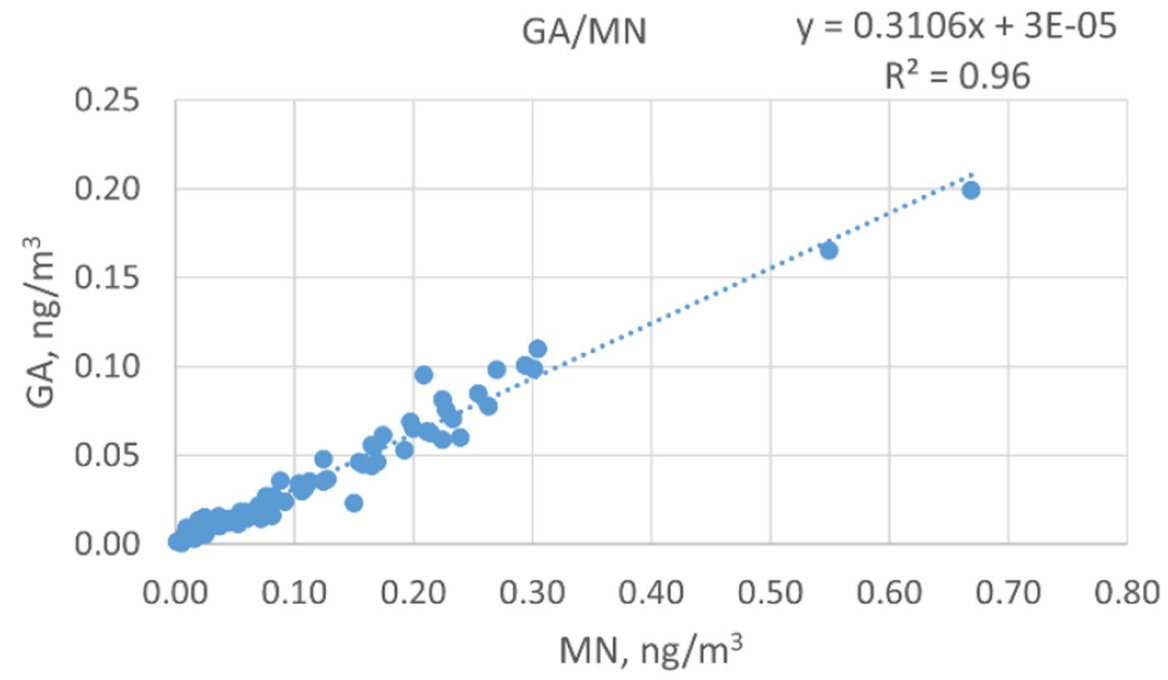

Table 5 Average concentration of total tracers sum to ambient aerosol $\left(\mathrm{TC} / \mathrm{PM}_{10}\right)$ ratio, levoglucosan concentration to ambient aerosol $\left(\mathrm{LG} / \mathrm{PM}_{10}\right)$ ratio, mannosan concentration to ambi- ent aerosol $\left(\mathrm{MN} / \mathrm{PM}_{10}\right)$ ratio, and galactosan concentration to ambient aerosol $\left(\mathrm{GA} / \mathrm{PM}_{10}\right)$ at both sites for measurement campaign, standard deviation in bracket

\begin{tabular}{|c|c|c|}
\hline Ratio & Rokitno & Zabrze \\
\hline Tracers sum/PM ${ }_{10}(\mathrm{SD})$ & $1.8 \times 10^{-2}\left(1.6 \times 10^{-2}\right)$ & $1.2110^{-2}\left(6.9 \times 10^{-3}\right)$ \\
\hline $\mathrm{LG} / \mathrm{PM}_{10}(\mathrm{SD})$ & $1.4 \times 10^{-2}\left(1.3 \times 10^{-2}\right)$ & $1.0 \times 10^{-2}\left(5.8 \times 10^{-3}\right)$ \\
\hline $\mathrm{MN} / \mathrm{PM}_{10}(\mathrm{SD})$ & $2.6 \times 10^{-3}\left(2.3 \times 10^{-3}\right)$ & $1.7 \times 10^{-3}\left(1.3 \times 10^{-3}\right)$ \\
\hline $\mathrm{GA} / \mathrm{PM}_{10}(\mathrm{SD})$ & $1.3 \times 10^{-3}\left(1.4 \times 10^{-3}\right)$ & $5.8 \times 10^{-4}\left(4.1 \times 10^{-4}\right)$ \\
\hline
\end{tabular}

Taking into consideration the results described elsewhere (Janoszka et al., 2020) from Krynica (the local environment of health resort) in the same time period as this study with concentration of the LG, MN, and GA equals to $139,14.2$, and 4.5, respectively, the $\mathrm{CD}$ between Krynica and Rokitno as well as Krynica and Zabrze was equal to 0.633 and 0.714 , respectively. The $\mathrm{CD}$ between Rokitno and Zabrze was equal to 0.178 . From this, it follows that assuming 0.3 as the limit value, Zabrze and Rokitno have a similar source of pollution. However, Krynica has a different emission source than Zabrze and Rokitno, as the coefficient of divergence is greater than 0.3. Moreover, the PM concentration from wood burning for Krynica according to the levoglucosan method (biomass smoke $\mathrm{PM}=\mathrm{LG} \times 7.35 \times 1.4)$ which was $1.43 \mu \mathrm{g} / \mathrm{m}^{3}$ and the restrictions introduced by the administrative authorities on the domestic heating (heating of residential buildings with gas) show different emission sources than for Rokitno and Zabrze.

\section{Conclusions}

In Zabrze, the $\mathrm{PM}_{10}$ concentration is about two times higher than in Rokitno. In December, January, and March, the average biomass burning concentration was higher in the industrial region Zabrze and in February the higher biomass tracer concentration was determined in the rural area Rokitno. Among the determined biomass burning tracers, levoglucosan is the most abundant compound; its mean percentage in total sum of tracers varies from 78.1 to $88.8 \%$. While galactosan was the least frequent, its mean percentage in total tracers sum varies from 4.4 to $6.4 \%$. The obtained results for the mean LG/MN and LG/ $(\mathrm{MN}+\mathrm{GA})$ concentration ratios indicate that in the case of industrial region the monosaccharides are 
most likely emitted from softwoods burning and in the rural area there was co-combustion of softwood with hardwood. Moreover, taking into consideration the average monthly temperatures and respective average monthly $\mathrm{LG} / \mathrm{MN}$ and $\mathrm{LG} /(\mathrm{MN}+\mathrm{GA})$ ratios, the material used for domestic heating is determined by temperature and localization. In colder months, the co-firing with hardwood dominated and in months with higher temperature the use of softwood was dominant. The agreement between biomass burning tracers is strong, with correlation coefficient from 0.60 to 0.96 . The biomass burning tracer concentration sum to $\mathrm{PM}_{10}$ concentration ratio was $1.77 \times 10^{-2}$ for Rokitno and $1.21 \times 10^{-2}$ for Zabrze. Considering the CD parameter, Zabrze and Rokitno have a similar source of pollution and Krynica has a different emission source.

Author Contribution Conceptualization: Marianna Czaplicka; Supervision: Marianna Czaplicka; Formal analysis: Katarzyna Janoszka; Methodology: Katarzyna Janoszka; Writing - original draft: Katarzyna Janoszka.

Funding This research was funded by the Institute of Environmental Engineering of the Polish Academy of Sciences basic (statutory) research project no. 1a-119/2019: "Temporal and spatial variability of the atmospheric aerosols chemical composition as a tool for evaluating the effects of implementing air protection programs in Poland."

Data Availability As the results of this research were done under an internal grant, they do not require to be available. The datasets generated/analyzed during the current study are available from the corresponding author on reasonable request.

\section{Declarations}

Conflict of Interest The authors declare no competing interests.

Open Access This article is licensed under a Creative Commons Attribution 4.0 International License, which permits use, sharing, adaptation, distribution and reproduction in any medium or format, as long as you give appropriate credit to the original author(s) and the source, provide a link to the Creative Commons licence, and indicate if changes were made. The images or other third party material in this article are included in the article's Creative Commons licence, unless indicated otherwise in a credit line to the material. If material is not included in the article's Creative Commons licence and your intended use is not permitted by statutory regulation or exceeds the permitted use, you will need to obtain permission directly from the copyright holder. To view a copy of this licence, visit http://creativecommons.org/licenses/by/4.0/.

\section{References}

Bae, M.-S., Lee, J. Y., Kim, Y.-P., Oak, M.-H., Shin, J.-S., Lee, K.-Y., Lee, H., Lee, S. Y., \& Kim, Y.-J. (2012). Analytical methods of levoglucosan, a tracer for cellulose in biomass burning, by four different techniques. Asian Journal of Atmospheric Environment, 6, 53-66. https://doi.org/10. 5572/ajae.2012.6.1.053

Bhattarai, H., Saikawa, E., Wan, X., Zhu, H., Ram, K., Gao, S., Kang, S., Zhang, Q., Zhang, Y., Wu, G., Wang, X., Kawamura, K., Fu, P., \& Cong, Z. (2019). Levoglucosan as a tracer of biomass burning: Recent progress and perspectives. Atmospheric Research, 220, 20-33. https://doi.org/ 10.1016/j.atmosres.2019.01.004

bin Abas, M. R., Oros, D. R., \& Simoneit, B. R. T. (2004). Biomass burning as the main source of organic aerosol particulate matter in Malaysia during haze episodes. Chemosphere, 55, 1089-1095. https://doi.org/10.1016/j.chemo sphere.2004.02.002

Caseiro, A., \& Oliveira, C. (2012). Variations in wood burning organic marker concentrations in the atmospheres of four European cities. Journal of Environmental Monitoring, 14, 2261-2269. https://doi.org/10.1039/c2em10849f

Dixon, R. W., \& Baltzell, G. (2006). Determination of levoglucosan in atmospheric aerosols using high performance liquid chromatography with aerosol charge detection. Journal of Chromatography A, 1109, 214-221. https://doi.org/ 10.1016/j.chroma.2006.01.021

Fabbri, D., Torri, C., Simoneit, B. R. T., Marynowski, L., Rushdi, A. I., \& Fabiańska, M. J. (2009). Levoglucosan and other cellulose and lignin markers in emissions from burning of Miocene lignites. Atmospheric Environment, 43, 2286-2295. https://doi.org/10.1016/j.atmosenv.2009. 01.030

Fuller, G. W., Tremper, A. H., Baker, T. D., Yttri, K. E., \& Butterfield, D. (2014). Contribution of wood burning to $\mathrm{PM}_{10}$ in London. Atmospheric. Environment., 87, 87-94. https:// doi.org/10.1016/j.atmosenv.2013.12.037

Galindo, N., Clemente, A., Yubero, E., Nicolás, J. F., \& Crespo, J. (2021). PM10 chemical composition at a residential site in the western Mediterranean: Estimation of the contribution of biomass burning from levoglucosan and its isomers. Environmental. Research, 196, 110394.

Gao, S., Hegg, D. A., Hobbs, P. V., Kirchstetter, T. W., Magi, B. I., \& Sadilek, M. (2003). Water-soluble organic components in aerosols associated with savanna fires in southern Africa: Identification, evolution, and distribution. Journal of Geophysical Research, 108(8491), 1-16. https://doi. org/10.1029/2002JD002324

Graham, B., Mayol-Bracero, O. L., Guyon, P., Roberts, G. C., Decesari, S., Facchini, C. M., Artaxo, P., Maenhaut, W., Köll, P., \& Andreae, M. O. (2002). Water-soluble organic compounds in burning aerosols over Amazonia: 1. Characterization by NMR and GC-MS. Journal of Geophysical Research, 107(8047), 1-16. https://doi.org/10.1029/ 2001JD000336

Hedberg, E., Johansson, C., Johansson, L., Swietlicki, E., \& Brorström-Lundén, E. (2006). Is levoglucosan a suitable quantitative tracer for wood burning? Comparison with receptor modeling on trace elements in Lycksele, Sweden. 
Journal of the Air \& Waste Management Association, 56, 1669-1678. https://doi.org/10.1080/10473289.2006. 10464572

Hennigan, C. J., Sullivan, A. P., Collet, J. L., Jr., \& Robinson, A. L. (2010). Levoglucosan stability in biomass burning particles exposed to hydroxyl radicals. Geophysical Research Letters, 37(L09806), 1-4. https://doi.org/10. 1029/2010GL43088

Hennigan, C. J., Miracolo, M. A., Engelhart, G. J., May, A. A., Presto, A. A., Lee, T., Sullivan, A. P., McMeeking, G. R., Coe, H., Wold, C. E., Hao, W.-M., Gilman, J. B., Kuster, W. C., de Gouw, J., Schichtel, B. A., Collett, J. L., Jr., Kreidenweis, S. M., \& Robinson, A. L. (2011). Chemical and physical transformations of organic aerosol from the photo-oxidation of open biomass burning emissions in an environmental chamber. Atmospheric Chemistry and Physics, 11, 7669-7686. https://doi.org/ 10.5194/acp-11-7669-2011

Janoszka, K., \& Czaplicka, M. (2019). Methods for the determination of levoglucosan and other sugar anhydrides as biomass burning tracers in environmental samples - A review. Journal of Separation Science, 42, 319-329. https://doi.org/10.1002/jssc.201800650

Janoszka, K., Czaplicka, M., \& Klejnowski, K. (2020). Comparison of biomass burning tracer concentrations between two winter seasons in Krynica Zdrój. Air Quality, Atmosphere and Health, 13, 379-385. https://doi. org/10.1007/s11869-020-00801-1

Jiang, N., Dong, Z., Xu, Y., Yu, F., Yin, S., Zhang, R., \& Tang, X. (2018). Characterization of PM10 and PM2.5 source profiles of fugitive dust in Zhengzhou. China Aerosol and Air Quality Research, 18, 314-329. https:// doi.org/10.4209/aaqr.2017.04.0132

Jordan, T. B., Seen, A. J., \& Jacobsen, G. E. (2006). Levoglucosan as an atmospheric tracer for woodsmoke. Atmospheric Environment, 40, 5316-5321. https://doi. org/10.1016/j.atmosenv.2006.03.023

Klejnowski, K., Janoszka, K., \& Czaplicka, M. (2017). Characterization and seasonal variation of organic and elemental carbon and levoglucosan in $\mathrm{PM}_{10}$ in Krynica Zdroj. Poland. Atmosphere, 8, 1-13. https://doi.org/10. 3390/atmos8100190

Kong, S., Ji, Y., Lu, B., Chen, L., Han, B., Li, Z., \& Bai, Z. (2011). Characterization of $\mathrm{PM}_{10}$ source profiles for fugitive dust in Fushun-a city famous for coal. Atmospheric Environment, 45, 5351-5365. https://doi.org/10. 1015/j.atmosenv.2011.06.050

Li, Z., Guo, S., Li, Z., Wang, Y., Hu, Y., Xing, Y., Liu, G., Fang, R., \& Zhu, H. (2020). PM $_{2.5}$ associated phenols, phthalates, and water soluble ions from five stationary combustion sources. Aerosol and Air Quality Research, 20, 61-71. https://doi.org/10.4209/aaqr.2019.11.0602

Mkoma, S. L., Kawamura, K., \& Fu, P. Q. (2013). Contribution of biomass/biofuel burning to organic aerosol and particulate matter in Tanzania, East Africa, based on analyses of ionic species, organic and elemental carbon, levoglucosan and mannosan. Atmospheric Chemistry and Physics, 13, 10325-10338. https://doi.org/10.5194/ acp-13-10325-2013

Oros, D. R., \& Simoneit, B. R. T. (2001). Identification and emission factors of molecular tracers in organic aerosols from biomass burning, part 1: Temperate climate conifers. Applied Geochemistry, 16, 1513-1544.

Piot, C., Jaffrezo, J.-L., Cozic, J., Pissot, N., Haddad, I. E., Marchand, N., \& Besombes, J.-L. (2012). Quantification of levoglucosan and its isomers by high performance liquid chromatography - Electrospray ionization tandem mass spectrometry and its applications to atmospheric and soil samples. Atmospheric Measurement Techniques, 5, 141-148. https://doi.org/10.5194/ amt-5-141-2012

PN-EN 12341:2014-07. Ambient air - Standard gravimetric measurement method to determine the concentration of mass fractions $\mathrm{PM}_{10}$ or $\mathrm{PM}_{2.5}$ particulate matter; The National Standards Authority of Ireland (NSAI): Dublin, Ireland, 2014

Poor, M. W. (2002). Levoglucosan in PM2.5 at the Fresno supersite. Journal of the Air \& Waste Management, 52, 3-4. https://doi.org/10.1080/10473289.2002.10470760

Puxbaum, H., Caseiro, A., Sánches-Ochoa, A., Kasper-Gielb, A., Claeys, M., Gelencsér, A., Legrand, M., Preunkert, S., \& Pio, C. (2007). Levoglucosan levels at background sites in Europe for assessing the impact of biomass combustion on the European aerosol background. Journal of Geophysical Research, 112(D23S05), 1-11. https://doi.org/10. 1029/2006JD008114

Resolution of the Sejmik no. V/36/1/2017, https://powietrze. slaskie.pl/index.php/content/uchwala-sejmiku-nr-v3612 017

Rodrigues, E. S., Perron, M. M. G., Strzelec, M., Proemse, B. C., Bowie, A. R., \& Paull, B. (2020). Analysis of levoglucosan and its isomers in atmospheric samples by ion chromatography with electrospray lithium cationisation Triple quadrupole tandem mass spectrometry. Journal of Chromatography A, 1610, 1-14. https://doi.org/10.1016/j. chroma.2019.460557

Saarikoski, S., Carbone, S., Decesari, S., Giulianelli, L., Angelini, F., Canagaratna, M., Ng, N. L., Trimborn, A., Facchini, M. C., Fuzzi, S., Hillamo, R., \& Worsnop, D. (2012). Chemical characterization of springtime submicrometer aerosol in Po Valley. Italy. Atmospheric of Chemistry and Physics, 12, 8401-8421. https://doi.org/10. 5194/acp-12-8401-2012

Saarnio, F., Teinilä, K., Aurela, M., Timonen, H., \& Hillamo, R. (2010). High-performance anion-exchange chromatography-mass spectrometry method for determination of levoglucosan, mannosan, and galactosan in atmospheric fine particulate matter. Analytical and Bioanalytical Chemistry, 398, 2253-2264. https://doi.org/10.1007/ s00216-010-4151-4

Schkolnik, G., \& Rudich, Y. (2006). Detection and quantification of levoglucosan in atmospheric aerosol: A review. Analytical and Bioanalytical Chemistry, 385, 26-33. https://doi.org/10.1007/s00216-005-0168-5

Schmidl, C., Marr, I. L., Caseiro, A., Kotianová, P., Berner, A., Bauer, H., Kasper-Giebl, A., \& Puxbaum, H. (2008). Chemical characterization of fine particle emissions from wood stove combustion of common woods grooving in mid-European Alpine regions. Atmospheric Environment, 42, 126-141. https://doi.org/10.1016/j.atmosenv.2007.09. 028 
Simoneit, B. R. T., Schauer, J. J., Nolte, C. G., Oros, D. R., Elias, V. O., Fraser, M. P., Rogge, W. F., \& Cass, G. R. (1999). Levoglucosan. A tracer for cellulose in biomass burning and atmospheric particles. Atmospheric Environment, 33, 173-182.

Sullivan, A. P., May, A. A., Lee, T., McMeeking, G. R., Kreidenweis, S. M., Akagi, S. K., Yokelson, R. J., Urbanski, S. P., \& Collett, J. L., Jr. (2014). Airborne characterization of smoke marker ratios from prescribed burning. Atmospheric Chemistry and Physics, 14, 10535-10545. https:// doi.org/10.5194/acp-14-10535-2014

Tan, J.-H., Duan, J.-C., Chai, F.-H., He, K.-B., \& Hao, J.-M. (2014). Source apportionment of size segregation fine/ ultrafine particle by PMF in Beijing. Atmospheric Research, 139, 90-100. https://doi.org/10.1016/j.atmos res.2014.01.007

Xu, C., \& You, C. (2021). Pristine atmospheric condition over the Third Pole: An insight from levoglucosan records. Geoscience Frontiers, 12, 851-856. https://doi.org/10. 1016/j.gsf.2020.09.003

Yin, X., de Foy, B., Wu, K., Feng, C., Kang, S., \& Zhang, Q. (2019). Gaseous and particulate pollutants in Lhasa, Tibet during 2013-2017: Spatial variability, temporal variations and implications. Environmental Pollution, 253, 68-77. https://doi.org/10.1016/j.envpol.2019.06.113

Zhang, T., Claeys, M., Cachier, H., Dong, S., Wang, W., Maenhaut, W., \& Liu, X. (2008). Identification and estimation of the biomass burning contribution to Beijing aerosol using levoglucosan as a molecular marker. Atmospheric Environment, 42, 7013-7021. https://doi.org/10.1016/j. atmosenv.2008.04.050

Zhang, Z., Gao, J., Zhang, L., Wang, H., Tao, J., Qiu, X., Chai, F., Li, Y., \& Wang, S. (2017). Observations of biomass burning tracers in $\mathrm{PM}_{2.5}$ at two megacities in North China during 2014 APEC summit. Atmospheric Environment, 169, 54-64. https://doi.org/10.1016/j.atmosenv.2017.09. 011

Publisher's Note Springer Nature remains neutral with regard to jurisdictional claims in published maps and institutional affiliations. 